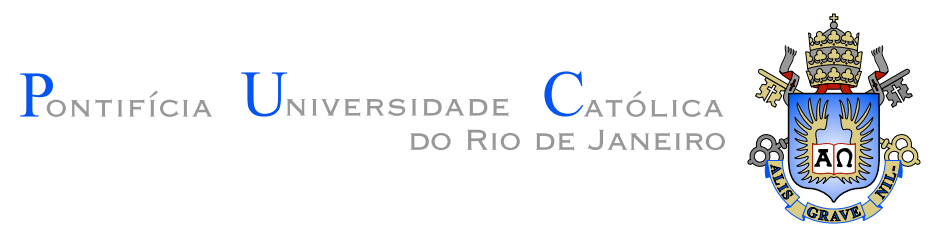

Flávio Henrique Marchesini de Oliveira

\title{
Viscoplastic Materials in Engineering Problems
}

Thesis presented to the Postgraduate Program in Mechanical Engineering of the Departamento de Engenharia Mecânica, PUCRio, as partial fulfillment of the requirements for the degree of Mestre em Engenharia Mecânica

Adviser : Prof. Paulo Roberto de Souza Mendes Co-Adviser: $\quad$ Prof. Mônica Feijó Naccache 


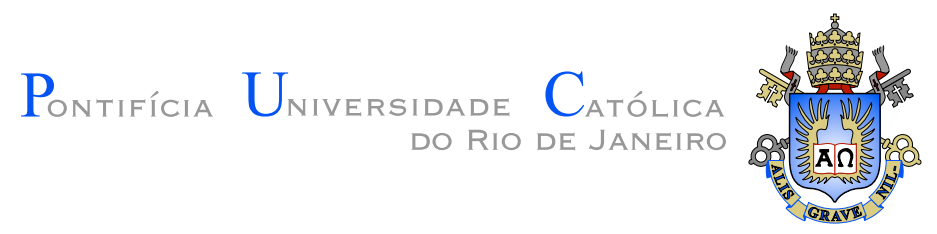

Flávio Henrique Marchesini de Oliveira

\title{
Viscoplastic Materials in Engineering Problems
}

Thesis presented to the Postgraduate Program in Mechanical Engineering of the Departamento de Engenharia Mecânica do Centro Técnico Científico da PUC-Rio, as partial fulfillment of the requirements for the degree of Mestre em Engenharia Mecânica. Approved by the following commission:

\author{
Prof. Paulo Roberto de Souza Mendes \\ Adviser \\ Departamento de Engenharia Mecânica - PUC-Rio \\ Prof. Mônica Feijó Naccache \\ Co-Adviser \\ Departamento de Engenharia Mecânica - PUC-Rio \\ Prof. Márcio da Silveira Carvalho \\ Departamento de Engenharia Mecânica - PUC-Rio
}

Prof. Roney Leon Thompson

Departamento de Engenharia Mecânica — UFF

Prof. José Eugênio Leal

Coordinator of the Centro Técnico Científico da PUC-Rio

Rio de Janeiro - December 17, 2008 
All rights reserved.

\section{Flávio Henrique Marchesini de Oliveira}

Flávio Marchesini graduated in Chemical Engineering from Federal University of Rio de Janeiro (UFRJ). Then he started to work with Rheology and non-Newtonian Continuum Mechanics in the Rheology Group (GReo) at PUC-Rio.

Bibliographic data

Marchesini, Flávio Henrique

Viscoplastic Materials in Engineering Problems / Flávio Henrique Marchesini de Oliveira; adviser: Paulo Roberto de Souza Mendes; co-adviser: Mônica Feijó Naccache — 2008.

132 f.: il. (color); 29,7 cm

1. Dissertação (Mestrado em Engenharia Mecânica) Pontifícia Universidade Católica do Rio de Janeiro, Rio de Janeiro, 2008.

Inclui Bibliografia.

1. Engenharia Mecânica - Teses. 2. Materiais Viscoplásticos. 3. Escoamentos. 4. Reometria. 5. Expansõescontrações. 6. Deslocamento. 7. Tubos Capilares. 8. Poços de Petróleo. I. de Souza Mendes, Paulo Roberto. II. Naccache, Mônica Feijó. III. Pontifícia Universidade Católica do Rio de Janeiro. Departamento de Engenharia Mecânica. IV. Título. 


\section{Acknowledgments}

This thesis has been produced by research efforts in the last years, since I started to work at the Rheology Group (GReo) of PUC-Rio. During this period I learned and worked with a lot of people who helped me in my first steps in the science and in obtaining the necessary resources to the researches described in this thesis.

I would like to thank my family, my sister, all of my friends and specially my mother for all contributions, incentive, support and apprenticeship during my life.

I also would like to thank my co-adviser Mônica Naccache for all teaching, support and partnership, and Marcio Carvalho, Luís Fernando Azevedo and Roney Thompson for the contributions to my education.

I am indebted to André Leibsohn and Cristiane Miranda for the financial support and partnership. I am also indebted to Eduardo Dutra who helped me in my first steps in rheology and in learning how to operate the instruments. I thank Tatiana Kerber and Júlio Barros for the support during my stay in the laboratory, and Deivid Santos, Bruno Fonseca and Wálter Teixeira who worked with me, and contributed with a lot of ideas at the construction of the experiments.

I am grateful to Teresa Juliet Bastidas Peña for all contributions that she gave me. And also, André Braghini for the support, Jane Celnik for helping me in the execution of the small scale experiments of the Chapter V, and Renata Pereira, a great friend, who was my partner for two years in a lot of experiments including the pilot scale experiments of chapter $\mathrm{V}$, and in the bureaucracy inherent to the research in Brazil. Moreover, I acknowledge Cátia Lima who was my student and prepared a lot of Carbopol dispersions for our measurements, and Alexandra Alicke for the special support at the end of this work.

I am particularly indebted to José Roberto Siffert, who is a great friend, and helped me through difficult moments and with whom I learned a lot of things in our partnership at the experiments of Chapter IV. I acknowledge with deep appreciation Priscilla Varges and Paula Mey, two of my best friends, who helped me in most of my first steps in the laboratory. Priscilla Varges and I realized the experiments of Chapter III, and Paula Mey helped me in the experiments of Chapter II.

Finally, I do not know how to thank my adviser Paulo Roberto de Souza Mendes, who I will never forget. I started to work with him in 2005 in a difficult moment and he was fundamental for my education and for my life, providing me all the supports necessary to realize this work and to surpass any problem. 


\section{Abstract}

Marchesini, Flávio Henrique; de Souza Mendes, Paulo Roberto; Naccache, Mônica Feijó. Viscoplastic Materials in Engineering Problems. Rio de Janeiro, 2008. 132p. Dissertação de Mestrado - Departamento de Engenharia Mecânica, Pontifícia Universidade Católica do Rio de Janeiro.

Viscoplastic or yield stress materials are found in a lot of natural processes, and in a wide variety of industries such as food, cosmetic, farmaceutical and petroleum. In these industries, knowing the accurate rheological properties of a viscoplastic material and its behavior in different flows are fundamental for the success of many operations. Nevertheless, the rheometry of this kind of material still presents some challenges, such as yield stress measurements, apparent wall slip, thixotropy and the breakdown of structure on loading the material into the rheometer geometry used. In addition to that, until now some phenomena in different flows involving viscoplastic materials are not well understood, and therefore more investigation is required. This thesis deals with viscoplastic materials, their rheological properties measurements, and their behavior in different kinds of flow. Moreover, a detailed analysis of flows such as viscometric, expansions-contractions, the displacements in capillary tubes, and the displacements inside oil wells was performed.

\section{Keywords}

Viscoplastic Materials. Flows. Rheometry. Expansionscontractions. Displacement. Capillary Tubes. Oil Wells. 


\section{Resumo}

Marchesini, Flávio Henrique; de Souza Mendes, Paulo Roberto; Naccache, Mônica Feijó. Materiais Viscoplásticos em Problemas de Engenharia. Rio de Janeiro, 2008. 132p. Dissertação de Mestrado - Departamento de Engenharia Mecânica, Pontifícia Universidade Católica do Rio de Janeiro.

Materiais viscoplásticos, os quais apresentam tensão limite de escoamento, podem ser encontrados em vários processos naturais e em diversas indústrias, tais como: alimentícia, de cosméticos, farmacêutica e do petróleo. Nessas indústrias o conhecimento preciso das propriedades reológicas dos materiais viscoplásticos e do comportamento desses materiais em diferentes escoamentos é fundamental para o sucesso de várias operações. Todavia, a reometria desse tipo de material ainda apresenta alguns desafios como as medidas de tensão limite de escoamento, deslizamento aparente, tixotropia e a quebra da microestrutura na colocação da amostra no reômetro. Além disso, existe o fato de que até hoje alguns fenômenos em diferentes escoamentos envolvendo materiais viscoplásticos ainda permanecem não tão bem compreendidos, o que requer uma investigação mais profunda. Nesse trabalho, uma abordagem dos materiais que apresentam comportamento viscoplástico, dos métodos utilizados para as medições de suas propriedades reológicas e do comportamento desses materiais em diferentes tipos de escoamento é realizada. Além disso, é executada uma análise detalhada de escoamentos, tais como: viscométricos, através de expansões-contrações, envolvendo deslocamentos em tubos capilares e de escoamentos envolvendo deslocamentos em poços de petróleo.

\section{Palavras-chave}

Materiais Viscoplásticos. Escoamentos. Reometria. Expansõescontrações. Deslocamento. Tubos Capilares. Poços de Petróleo. 


\section{Contents}

I Introduction $\quad 13$

$\begin{array}{lll}\text { I.1 Basic concepts } & 13\end{array}$

$\begin{array}{lll}\text { I.2 Viscoplastic materials } & 17\end{array}$

$\begin{array}{lll}\text { I.3 Viscoplastic materials models } & 19\end{array}$

I.4 Overview 22

1.5 Note 23

II Rheometry $\quad 24$

II.1 Introduction 24

II.2 Analysis 26

Experimental measurements $\quad 26$

Viscosity function and rheological parameters $\quad 27$

Governing equations and boundary conditions $\quad 28$

$\begin{array}{lll}\text { II.3 Experiments } & 29\end{array}$

II.4 Numerical Solution 30

II.5 Results and Discussion 31

Experimental Results 31

Numerical Results 36

Comparison between experimental and numerical results 40

II.6 Final Remarks 41

$\begin{array}{lll}\text { II.7 Note } & 42\end{array}$

III Expansions-contractions Flows $\quad 43$

III.1 Introduction 43

III.2 Analysis 45

Viscosity function and rheological parameters $\quad 45$

Governing equations and boundary conditions 46

$\begin{array}{ll}\text { Governing parameters } & 47\end{array}$

III.3 Numerical Solution $\quad 47$

III.4 The Experiments $\quad 49$

The visualization experiments $\quad 49$

Rheology of the Carbopol dispersions $\quad 51$

III.5 Results and Discussion 53

Flow visualization results $\quad 53$

Numerical results $\quad 56$

Comparison between experimental and numerical results 62

III.6 Final Remarks 64

III.7 Note $\quad 64$

IV Displacements in Capillary Tubes $\quad 65$ 
IV.1 Introduction $\quad 65$

$\begin{array}{ll}\text { IV.2 Analysis } & 68\end{array}$

Viscosity function and rheological parameters 68

Governing equations and boundary conditions $\quad 69$

$\begin{array}{ll}\text { Governing parameters } & 70\end{array}$

$\begin{array}{ll}\text { IV.3 The Experiments } & 71\end{array}$

$\begin{array}{ll}\text { The displacement experiments } & 71\end{array}$

Rheology of the Carbopol dispersions $\quad 73$

IV.4 Results and Discussion $\quad 75$

Results for the fully-developed flow $\quad 75$

Fractional mass coverage results $\quad 79$

IV.5 Final Remarks $\quad 83$

IV.6 Note $\quad 84$

V Displacements inside Oil Wells $\quad 85$

$\begin{array}{lll}V .1 & \text { Introduction } & 85\end{array}$

$\begin{array}{ll}\text { V.2 Analysis } & 87\end{array}$

Viscosity function and rheological parameters $\quad 87$

Governing parameters $\quad 88$

$\begin{array}{lll}\text { V.3 Experimental Investigation } & 90\end{array}$

Small scale experiments $\quad 90$

Pilot scale experiments $\quad 91$

Large scale experiments $\quad 94$

Rheological measurements $\quad 96$

$\begin{array}{lll}\text { V.4 Numerical Solution } & 97\end{array}$

V.5 Results and Discussion $\quad 97$

$\begin{array}{ll}\text { Small scale } & 97\end{array}$

Pilot scale $\quad 99$

Large scale 108

$\begin{array}{lll}\text { V.6 Final Remarks } & 119\end{array}$

$\begin{array}{lll}\text { V.7 Note } & 120\end{array}$

$\begin{array}{lr}\text { VI Conclusions } & 121\end{array}$

$\begin{array}{lr}\text { Bibliography } & 123\end{array}$ 


\section{List of Figures}

$\begin{array}{lll}\text { I.1 The dimensionless shear stress function. } & 21\end{array}$

II.1 Scheme of bob-in-cup geometry. 26

II.2 The geometries. 29

II.3 Flow Curve of Carbopol dispersion 0,17\% - investigation of the apparent slip region.

II.4 Viscosity of Carbopol dispersion $0,17 \%$ as a function of shear stress - investigation of the apparent slip region. 32

II.5 Flow Curve of different Carbopol dispersions without apparent slip. 32

II.6 Thixotropic Curves of Carbopol dispersion 0,15\%. 33

II.7 Creep test realized in a UDS 200 Paar-Physica with a grooved Couette geometry of Carbopol dispersion 0,15\%. 34

II.8 Inner and outer apparent wall slip velocities. 35

II.9 Velocity and strain rate for the smooth Couette geometry, and $\dot{\gamma}_{\text {exp }} / \dot{\gamma}_{1}=4.4 \times 10^{-3}$.

II.10 Velocity and strain rate for the smooth Couette geometry, and $\dot{\gamma}_{\text {exp }} / \dot{\gamma}_{1}=4.4$.

II.11 Velocity and strain rate for the vane geometry, and $\dot{\gamma}_{\text {exp }} / \dot{\gamma}_{1}=$ $4.4 \times 10^{-3}$.

II.12 Velocity and strain rate for the vane geometry, and $\dot{\gamma}_{\text {exp }} / \dot{\gamma}_{1}=4.4 .38$

II.13 Velocity and strain rate for the grooved Couette geometry, and $\dot{\gamma}_{\text {exp }} / \dot{\gamma}_{1}=4.4 \times 10^{-3}$.

II.14 Velocity and strain rate for the grooved Couette geometry, and $\dot{\gamma}_{\text {exp }} / \dot{\gamma}_{1}=4.4$.

II.15 Velocity profile for the three geometries and dimensionless experimental outer wall shear rate equal to $4.4 \times 10^{-3}$ and 4.4.

II.16 Strain rate profile for the three geometries and dimensionless experimental outer wall shear rate equal to $4.4 \times 10^{-3}$ and $4.4 . \quad 39$

II.17 Inner and outer shear stress for the three geometries.

II.18 Comparison of inner wall shear stress between experimental and numerical results.

III.1 The geometry.

III.2 Schematics of the apparatus. 50

III.3 The flow curves of the Carbopol dispersions. 51

III.4 The dimensionless viscosity of the Carbopol dispersions as a function of the dimensionless shear stress.

III.5 Effect of $\tau_{R}^{*}$ on the yield surface location, for $J=2.8 \times 10^{6}$, $n=4.8$ (Carbopol 0.09\%), $L_{o} / R_{o}=1.0$, and $R_{o} / R=5$. From left to right, the pictures correspond respectively to $\tau_{R}^{*}=$ 3.0, 5.3, 8.4, 10.5, and 0.0.

III.6 Effect of $L_{o} / R_{o}$ on the yield surface location, for $J=2.8 \times 10^{6}$, $n=4.8$ (Carbopol 0.09\%), $\tau_{R}^{*}=5.3$, and $R_{o} / R=5$. From left to right, the pictures correspond respectively to $L_{o} / R_{o}=1.0,1.5$, and 2.0 . 
III.7 Effect of $R_{o} / R$ on the yield surface location, for $J=2.8 \times 10^{6}$, $n=4.8$ (Carbopol 0.09\%), $\tau_{R}^{*}=5.3$, and $L_{o} / R_{o}=1.0$. From left to right, the pictures correspond respectively to $R_{o} / R=3$ and 5 .

III.8 Effect of rheology on the yield surface location, for $\tau_{R}^{*}=4.0$, $R_{o} / R=3$, and $L_{o} / R_{o}=1.5$. From left to right, the pictures correspond respectively to $(J, n)=\left(1.8 \times 10^{6}, 0.42\right)$ and $(2.8 \times$ $\left.10^{6}, 0.48\right)$.

III.9 Displacement efficiency as a function of $\tau_{R}^{*}$. Carbopol $0.09 \%$.

III.10 Displacement efficiency as a function of $\tau_{R}^{*}$. Carbopol $0.11 \%$.

III.11 Isobands of $\tau^{*} . R_{o} / R=6.3, L_{o} / R_{o}=1, J=18000, n=0.4$, $\tau_{R}^{*}=1.9$

III.12 Isobands of $\tau^{*} . R_{o} / R=6.3, L_{o} / R_{o}=1, J=18000, n=0.4$, $\tau_{R}^{*}=3.6$

III.13 Displacement efficiency as a function of $R_{o} / R . \tau_{R}^{*}=3.6, J=$ $18000, n=0.4$.

III.14 Head loss and displacement efficiency as a function of $L_{o} / R_{o}$. $\tau_{R}^{*}=3.6, R_{o} / R=6.3, n=0.4, J=18000$.

III.15 Displacement efficiency as a function of $\tau_{R}^{*} . R_{o} / R=6.3, J=$ $18000, n=0.4$.

III.16 Head loss and displacement efficiency as a function of the jump number. $\tau_{R}^{*}=3.6, R_{o} / R=6.3, n=0.4, J=18000$.

III.17 Head loss and displacement efficiency as a function of the powerlaw index. $\tau_{R}^{*}=3.6, R_{o} / R=6.3, L_{o} / R_{o}=1, J=18000$.

III.18 Head loss as a function of $R_{o} / R . \tau_{R}^{*}=3.6, J=18000, n=0.4$.

III.19 Head loss as a function of $\tau_{R}^{*} . R_{o} / R=6.3, J=18000, n=0.4$.

III.20 Comparison between the predicted and observed yield surface locations. $R_{o} / R=5$, and $L_{o} / R_{o}=1$. Left: Carbopol $0.09 \%$ and $\tau_{R}^{*}=4.0$; right: Carbopol $0.11 \%$ and $\tau_{R}^{*}=2.6$.

III.21 Predicted axial velocity and stress intensity radial distributions at the symmetry plane. $R_{o} / R=5, L_{o} / R_{o}=1$, and $\tau_{R}^{*}=4.0$. $J=4.0 \times 10^{5}$ and $n=0.48$.

IV.1 Displacement of a viscoplastic material in a capillary.

IV.2 The boundary conditions as described from a reference frame attached to the bubble front.

IV.3 The experimental setup. $\quad 72$

IV.4 The flow curves of the Carbopol dispersions. 73

IV.5 The dimensionless viscosity functions of the Carbopol dispersions. 74

IV.6 Dimensionless average velocity as a function of the dimensionless wall shear stress.

$\begin{array}{lll}\text { IV.7 Dimensionless viscosity profiles. } & 77\end{array}$

IV.8 Dimensionless velocity profiles. 78

IV.9 Interface shapes. (a) Carbopol 0.09\%; (b) Carbopol 0.11\%; (c) Carbopol 0.15\%; (d) Carbopol 0.17\%. The bubble speed increases from left to right; see Table IV.1 for the corresponding $C a_{p}, \bar{u}^{*}$, $\tau_{R}^{*}$, and $m$ values.

IV.10 The fractional mass coverage as a function of the average velocity. 82 
$\begin{array}{lll}\text { V.1 The geometry. } & 88\end{array}$

V.2 Small scale apparatus. $\quad 90$

V.3 Pilot scale apparatus $1 . \quad 92$

V.4 Pilot scale apparatus 2. 93

V.5 Large scale apparatus. $\quad 94$

V.6 Interface evolution. Newtonian liquid 2 (glycerol) displacing a Newtonian liquid 1 (lower viscosity oil). Time increases from left to right.

V.7 Interface evolution. Viscoplastic material (Carbopol dispersion) displacing a Newtonian liquid (low viscosity oil). Time increases from left to right.

V.8 Interface evolution. Newtonian liquid (glycerol) displacing a Viscoplastic material (Carbopol dispersion). Time increases from left to right.

V.9 Interface evolution for the vertical case $\left(0^{0}\right)$. Carbopol $0.10 \%$ (blue) displacing Carbopol $0.08 \%$ (white). Time increases from left to right, and from the top to the bottom.

V.10 Interface evolution for the inclined case $\left(45^{\circ}\right)$. Carbopol $0.10 \%$ (blue) displacing Carbopol $0.08 \%$ (white). Time increases from left to right, and from the top to the bottom.

V.11 Interface evolution for the horizontal case $\left(90^{\circ}\right)$. Carbopol $0.10 \%$ (blue) displacing Carbopol $0.08 \%$ (white). Time increases from left to right, and from the top to the bottom.

V.12 Comparison between experimental and numerical results of Carbopol $0.10 \%$ displacing Carbopol $0.08 \%$ in the vertical case $\left(0^{0}\right)$. (a) and (b) correspond to the numerical results. (c) and (d) correspond to the experimental results.

V.13 Comparison between experimental and numerical results of Carbopol $0.10 \%$ displacing Carbopol $0.08 \%$ in the inclined case $\left(45^{0}\right)$. (a) and (b) correspond to the numerical results. (c) and (d) correspond to the experimental results.

V.14 Comparison between experimental and numerical results of Carbopol $0.10 \%$ displacing Carbopol $0.08 \%$ in the horizontal case $\left(90^{\circ}\right)$. (a) and (b) correspond to the numerical results. (c) and (d) correspond to the experimental results.

V.15 Volume fraction of the Carbopol $0.08 \%$ for the three cases, calculated by the numerical solution.

V.16 Experimental density and the density that would be obtained if the displacement were perfect versus volume of cement slurry used to displace the spacer.

V.17 Displacement of the spacer (light color) by the cement slurry (black color). (a) Downward displacement, and (b) upward displacement.

V.18 End of the displacement of the spacer (light color) by the cement slurry (black color). (a) Downward displacement, and (b) upward displacement. 
V.19 Experimental density and the density that would be obtained if the displacement were perfect versus volume of water used to displace the cement slurry.

V.20 Displacement of the cement slurry by water (13 L). (a) Downward displacement, and (b) upward displacement.

V.21 Experimental and numerical densities versus volume of spacer used to displace the drilling mud, compared with the density that would be obtained if the displacement were perfect.

V.22 Interface evolution of the displacement of the drilling mud by the spacer material predicted by the numerical solution of the governing equations.

V.23 Experimental and numerical densities versus volume of cement slurry used to displace the spacer, compared with the density that would be obtained if the displacement were perfect.

V.24 Interface evolution of the displacement of the spacer material by the cement slurry predicted by the numerical solution of the governing equations.

V.25 Experimental and numerical densities versus volume of spacer used to displace the cement slurry, compared with the density that would be obtained if the displacement were perfect.

V.26 Interface evolution of the displacement of the cement slurry by the spacer material predicted by the numerical solution of the governing equations.

V.27 Pictures of slices of the tube after the cement slurry was displaced by the spacer.

V.28 Interface evolution of the cement plug 1 experiment predicted by the numerical solution of the governing equations.

V.29 Pictures of the cement plug 1. (a) The hole plug, and (b) slice located at the top of the plug.

V.30 Interface evolution of the cement plug 2 experiment predicted by the numerical solution of the governing equations.

V.31 Pictures of the cement plug 2. (a) The hole plug, and (b) and (c) views of the slice located between $2.75 \mathrm{~m}$ and $3.05 \mathrm{~m}$ from the bottom.

V.32 Pictures of the cement plug 2: views of the slice located between $3.05 \mathrm{~m}$ and $3.35 \mathrm{~m}$ from the bottom.

V.33 Pictures of the cement plug 2: views of the slice located between $2.15 \mathrm{~m}$ and $2.45 \mathrm{~m}$ from the bottom. 


\section{List of Tables}

II.1 Geometries and meshes. 30

III.1 Mesh test for $\tau^{*}=3.7, J=18000$ and $n=0.4$. 48

III.2 Meshes employed. 49

IV.1 Plastic capillary number, flow rate, and wall shear stress values of the flows shown in Fig. IV.9.

V.1 Properties of the materials used in apparatus $1 . \quad 91$

V.2 Properties of the materials used in apparatus 2. 93

V.3 Large scale physical simulation - material replacement. 95

V.4 Large scale physical simulation - cement plug 1.

V.5 Large scale physical simulation - cement plug 2. 